\title{
ANALISIS YURIDIS TERHADAP PELANGGARAN HAK CIPTA PERMAINAN VIDEO (VIDEO GAMES) BERUPA PEMBAJAKAN SECARA ONLINE
}

\section{Vania Irawan}

Universitas Indonesia

Contact: vaniairawan98@gmail.com

Diterima: 14 November 2020

Direvisi:

Disetujui: 30 Desember 2020

Hak Cipta: (C)2018

Halaman: $35-52$

\begin{abstract}
Video games are games that can be played by one or more people which are produced by computer programs on a television screen or other display screen. Video games are included in a protected work in accordance with Article 40 paragraph (1) letter $r$ and Article 59 paragraph (1) letter d of Law No. 28 of 2014 on Copyright. The nature and elements of video games are complex, creating confusion regarding the video game category. In some countries, video games are included in the category of computer programming while in other countries, video games are included in the category of audiovisual. In addition, another difficulty that arises is the copyright holder of video games because as we know, the video games that are widely played these days, are created by game developers who consist of not only one or two people but hundreds of experts and professionals. Then, another problem is regarding video game online piracy. This has happened so often that it becomes one of the game developers concern and restlesness about every time they launch a new video game. So it also examines the prevention and protection of video games being pirated online.
\end{abstract}




\section{PENDAHULUAN}

Video games atau permainan video merupakan hal yang sudah tidak asing bagi masyarakat Indonesia dan sudah dikenal di seluruh dunia. Video games dapat menjadi sarana untuk hobi atau bahkan menjadi salah satu sumber penghasilan. Hal tersebut karena banyaknya youtubers gamers, organisasi atau grup gamers yang sering mengikuti lomba game baik dalam skala nasional maupun internasional, menjadikan game sebagai salah satu atau bahkan penghasilan utama mereka.

Video games ditentukan berdasarkan platform yang digunakan, antara lain permainan arkade (arcade games), permainan konsol (console games), dan permainan komputer (PC games). Seiring dengan perkembangan teknologi, industri video games mulai mengembangkan platform nya melalui smartphone, komputer tablet, dan virtual reality. Dikutip dari Oxford Languages, video games adalah:

"a game played by electronically manipulating images produced by a computer program on a television screen or other display screen." permainan yang dimainkan dengan memanipulasi gambar secara elektronik yang dihasilkan oleh program komputer pada layar televisi atau layar tampilan lainnya.

Sejarah video games dimulai pada tahun 1952. Seorang professor yang berasal dari Inggris, bernama A.S Douglas membuat permainan OXO atau yang dikenal dengan permainan tic tac toe sebagai bagian dari disertasinya dalam menempuh program doktoral di Universitas Cambridge. Lalu, pada tahun 1958, William Higinbotham membuat permainan video yang bernama Tennis for Two di sebuah komputer analog yang besar.

Pada tahun 1962, Steve Russel dari Institut Teknologi Massachusetts menemukan sebuah permainan video bernama Spacewar!, yang merupakan game pertempuran ruang angkasa berbasis komputer. Komputer yang digunakan pada saat itu adalah PDP-1 (Programmed Data Processor-1) yang kemudian merupakan komputer yang paling mutakhir yang banyak ditemukan di universitas. Spacewar! merupakan video games pertama yang bisa dimainkan di beberapa instalasi komputer.

Pada tahun 1967, seorang pengembang dari Sanders Associate, Inc., yang dipimpin oleh Ralph Baer, menciptakan "The Brown Box" yaitu sebuah prototype multiplayer (prototipe yang memungkinkan sebuah game dimainkan oleh lebih dari satu orang), sistem multiprogram video games yang dapat dimainkan di televisi. Hal tersebut kemudian menjadi awal mula perkembangan video games dan industri video games mencapai pencapaian penting di akhir tahun 1970 dan awal tahun 1980, termasuk:

- Rilisnya game arcade Space Invaders di tahun 1978. 
- Peluncuran Activasion, pengembang game pihak ketiga pertama (yang mengembangkan perangkat lunak tanpa membuat konsol atau lemari arkade) di tahun 1979.

- Pengenalan game paling populer di Jepang, Pac Man ke Amerika Serikat.

- Kreasi Nintendo tentang Donkey Kong, yang memperkenalkan karakter Mario kepada dunia.

- Microsoft merilis game Flight Simulator pertamanya. (A\&E Television Networks, 2017).

Salah satu aspek yang berkaitan erat dengan permainan video adalah mengenai hak kekayaan intelektual. Dalam satu video games, melekat beberapa bidang kekayaan intelektual seperti paten, merek, dan hak cipta. Sebagai contoh, dalam game Mario Bros terdapat hak cipta dalam software, desain karakter Mario dan Luigi, visual dalam permainan, dan musik pengiring. Lalu terdapat hak paten dalam teknologi yang digunakan untuk membuat game Mario Bros sehingga game Mario Bros dapat dimainkan di sebuah konsol dan terdapat hak merek dalam merek Mario Bros sebagai video game ataupun merek Mario Bros dalam penjualan merchandise.

Sifat dari permainan video yang kompleks dan lintas sektor, menimbulkan tantangan terhadap perlindungan permainan video terutama dalam hak cipta. Meskipun dalam Pasal 2 Berne Convention memberikan dasar yang kuat dalam perlindungan permainan video. Namun pada kenyataannya dalam satu video games yang diciptakan, terdapat beberapa hak cipta dari pencipta yang berbeda. Itu lah yang kemudian membuat perlindungan terhadap video games jauh lebih kompleks. Video game modern berisi setidaknya dua bagian utama, yaitu:

- Elemen audiovisual (termasuk gambar, rekaman video dan suara); dan

- Perangkat lunak (software), yang secara teknis mengelola elemen audiovisual dan memungkinkan pengguna untuk berinteraksi dengan berbagai elemen game.

Oleh karena terdapat dua bagian utama yang berbeda, akibatnya pertanyaan terkait aturan yang berlaku untuk video games tidak memiliki jawaban yang jelas. Di beberapa negara, video games dikategorikan sebagai program komputer karena sifatnya yang spesifik dan ketergantungannya pada perangkat lunak. Sedangkan, di beberapa negara lainnya, video games dikategorikan sebagai karya audiovisual. Selain itu, permasalahan kompleks lainnya adalah apabila terdapat pengembangan video game yang melibatkan orang-orang yang ahli di bidang yang bersangkutan (specialists), maka siapa saja yang memiliki hak cipta dalam permainan video tersebut (WIPO, Copyright, Video Games).

Di Indonesia, perlindungan hak cipta terkait permainan video, diatur dalam Undang-Undang Nomor 28 Tahun 2014 tentang Hak Cipta (selanjutnya disebut sebagai UUHC). Namun dalam UUHC tidak ada pengertian mengenai 
permainan video maupun aturan spesifik terkait permainan video. Di dalam UUHC, permainan video dikategorikan sebagai ciptaan, hal tersebut dilihat dari rumusan Pasal 40 ayat (1) dan Pasal 59 ayat (1), bahwa:

Pasal 40 ayat (1)

"Ciptaan yang dilindungi meliputi Ciptaan dalam bidang ilmu pengetahuan, seni, dan sastra, terdiri atas: .....r. permainan video"

Pasal 59 ayat (1)

"Pelindungan Hak Cipta atas Ciptaan: ....d. permainan video"

Selain itu, pengertian ciptaan menurut Pasal 1 angka 3 UUHC adalah :

"Ciptaan adalah setiap hasil karya cipta di bidang ilmu pengetahuanseni, dan sastra yang dihasilkan atas inspirasi, kemampuan, pikiran, imajinasi, kecekatan, keterampilan, atau keahlian yang diekspresikan dalam bentuk nyata".

Meskipun permainan video diatur dalam UUHC, namun terdapat beberapa permasalahan hukum yaitu mengenai pemegang hak cipta atas video games apabila terdapat beberapa orang atau specialists yang terlibat dalam pembuatan dan perkembangan suatu permainan video. Mengingat dalam pembuatan dan pengembangan suatu permainan video hampir tidak mungkin hanya dilakukan seorang diri, terlebih lagi jika permainan video tersebut sangat kompleks dan membutuhkan tenaga ahli lainnya.

Lalu permasalahan selanjutnya adalah mengenai masih banyaknya pelanggaran- pelanggaran terhadap hak cipta dalam permainan video (terutama pembajakan permainan video secara online) menimbulkan kerugian bagi perusahaan game, menghambat perkembangan ekonomi negara karena ada sumber pendapatan negara yang hilang, dan kekhawatiran bagi game developer di Indonesia (game developer adalah orang atau perusahaan yang mengembangkan sebuah atau beberapa game, WIPO, 2013: 44). Sehingga menimbulkan pertanyaan mengenai faktor-faktor apa saja yang mendorong terjadinya pembajakan permainan video secara online. Lalu yang terakhir mengenai perlindungan terhadap permainan video yang dibajak secara online.

Oleh karena itu menurut penulis, hal-hal di atas patut dikaji lebih lanjut, mengingat perkembangan permainan video yang semakin pesat di era digital ini dan semakin banyaknya game developer lokal asli Indonesia (baik yang masih baru maupun yang sudah terkenal di dunia).

\section{METODOLOGI PENELITIAN}

Metode penelitian yang digunakan adalah yuridis normatif yaitu metode atau cara yang dipergunakan di dalam penelitian hukum yang dilakukan dengan cara meneliti bahan pustaka yang ada (Soerdjono Soekanto \& Sri Mamudji, 2009:13).

Pendekatan yang dilakukan dalam penelitian ini adalah pendekatan undangundang (statute approach) yaitu pendekatan yang dilakukan dengan 
menelaah semua undang-undang dan regulasi yang bersangkutan dengan isu hukum yang ditangani (Peter Mahmud Marzuki, 2019: 133). Dalam penelitian ini, penulis menelaah Undang-Undang No. 28 Tahun 2014 tentang Hak Cipta.

Sumber hukum yang digunakan dalam penelitian ini adalah sumber hukum primer dan sumber hukum sekunder. Sumber hukum primer meliputi semua produk atau dokumen hukum yang dibuat oleh pejabat negara yang berwenang membuat hukum; semua dokumen hukum yang mengikat para pihak yang membuatnya; dan dokumen hukum yang juga memiliki kekuatan mengikat (otoritatif). Sedangkan sumber hukum sekunder adalah semua bahan tentang hukum yang tidak bersifat otoritatif ataupun menimbulkan akibat hukum, melainkan bersifat persuasif, namun layak menjadi rujukan dan penunjang bagi sumber atau bahan hukum primer (Elly Erawaty, 2010: 10).

\section{HASIL DAN PEMBAHASAN}

\section{Pemegang Hak Cipta dalam Permainan Video}

Pengertian mengenai pemegang hak cipta dirumuskan dalam Pasal 1 angka 4, bahwa :

"Pemegang Hak Cipta adalah Pencipta sebagai pemilik Hak Cipta, pihak yang menerima hak tersebut secara sah dari Pencipta, atau pihak lain yang menerima lebih lanjut hak dari pihak yang menerima hak tersebut secara sah."
Dari pengertian di atas, dapat disimpulkan bahwa pemegang hak cipta tidak harus selalu pencipta melainkan dapat pula pihak yang menerima hak tersebut secara sah dari pencipta atau pihak lain yang menerima lebih lanjut hak tersebut.

Seperti yang telah disinggung sebelumnya dalam latar belakang, bahwa salah satu tantangan dalam menentukan pemegang hak cipta dalam permainan video adalah karena unsur-unsur atau elemen-elemen dari permainan video yang kompleks. Dalam sebuah permainan video setidaknya terdapat tiga elemen kreatif sebagai berikut: (WIPO Magazine, 2014). 


\begin{tabular}{|c|c|c|}
\hline $\begin{array}{c}\text { Elemen audio } \\
\text { (Audio elements) }\end{array}$ & $\begin{array}{c}\text { Elemen video } \\
\text { (Video elements) }\end{array}$ & $\begin{array}{c}\text { Kode komputer } \\
\text { [Computer code } \\
\text { (source code } \\
\text { and object } \\
\text { code)] }\end{array}$ \\
\hline $\begin{array}{l}\text { Komposisi musik } \\
\text { (Musical } \\
\text { compositions) }\end{array}$ & $\begin{array}{c}\text { Gambar fotografi } \\
\text { (Photographic } \\
\text { images) seperti Gif, } \\
\text { Tiff, Jpeg }\end{array}$ & $\begin{array}{c}\text { Primary game } \\
\text { engine or engines }\end{array}$ \\
\hline $\begin{array}{l}\text { Rekaman suara } \\
\text { (Sound } \\
\text { Recordings) }\end{array}$ & $\begin{array}{l}\text { Gambar bergerak } \\
\text { yang diambil } \\
\text { secara digital } \\
\text { (Digitally captured } \\
\text { moving images) } \\
\text { seperti Mpeg }\end{array}$ & $\begin{array}{l}\text { Kode tambahan } \\
\text { (Ancillary code) }\end{array}$ \\
\hline $\begin{array}{l}\text { Suara, bunyi } \\
\text { (Voice) }\end{array}$ & $\begin{array}{c}\text { Animasi } \\
\text { (Animation) }\end{array}$ & Plug-ins \\
\hline $\begin{array}{l}\text { Efek suara yang } \\
\text { diimpor (Imported } \\
\text { sound effects) }\end{array}$ & Teks (Text) & $\begin{array}{l}\text { Komentar } \\
\text { (Comments) }\end{array}$ \\
\hline $\begin{array}{c}\text { Efek suara } \\
\text { internal (Internal } \\
\text { sound effects) }\end{array}$ & & \\
\hline
\end{tabular}

Keterangan :

- Game engine adalah sebuah perangkat lunak atau bisa berdiri sebagai library yang dapat digunakan untuk membuat game. Game engine memegang peranan penting bagi developer game (Gamelab, mengenal Game Engine, 2018).

- Plugin adalah software tambahan untuk menjalankan program.

Selain elemen-elemen yang telah disebutkan di atas, hal-hal lain yang dilindungi dengan hak cipta antara lain naskah (script) dalam permainan video, karya tulis lainnya dari permainan video; karakter (well-developed characters) dalam permainan video; koreografi (choreographies) dan pantomim; peta (maps) dan karya arsitektur.

Selain elemen-elemen permainan video yang cukup banyak, permainan video juga melibatkan banyak pihakpihak atau specialists dalam pembuatan dan pengembangannya. Pihak-pihak yang terlibat dalam pembuatan dan pengembangan permainan video, antara lain namun tidak terbatas pada :

- $\quad$ Produser (producer), mengawasi pembuatan permainan video. Produser permainan video memiliki peran yang mirip dengan direktur film;

- Perancang permainan (game designers);

- Seniman (artist) yang membuat seni visual dalam permainan video;

- Programer atau orang yang ahli di bidang teknik (Programmer or Engineer), membuat dan menerapkan kode-kode dalam permainan video;

- Perancang audio (audio designers), bertanggung jawab untuk memberikan efek suara atau elemen suara-suara lain yang berkaitan dengan permainan video;

- Pelaku pertunjukan yang berkaitan dengan suara dan gerak; dan

- Produser audiovisual dan rekaman audio. (WIPO, 2013: 9).

Meskipun banyak pihak-pihak atau specialists yang terlibat di dalam pembuatan dan perkembangan 
permainan video, namun pada umumnya informasi terkait pihak-pihak yang membuat dan mengembangkan game hanya seputar pada game developer, game publisher game publisher adalah sebuah perusahaan yang menerbitkan video game yang telah dibuat sendiri, atau yang telah diperoleh dari game developer atau memperoleh hak distribusi, WIPO, 2013: 45), dan/atau kreator dari permainan video tersebut. Oleh karena itu, hanya sedikit orang yang mengetahui siapa pihak-pihak atau specialists yang terlibat di dalam pembuatan dan pengembangan permainan video.

Oleh karena banyaknya pihak-pihak atau specialists yang terlibat di dalam pembuatan dan pengembangan permainan video, maka terdapat dua kemungkinan untuk menentukan pemegang hak cipta dalam permainan video. Pertama, orang-orang atau pihak yang terlibat merupakan orang-orang yang bekerja di bawah game developer dan terdapat hubungan kerja antara orang tersebut dengan perusahaan. Kedua, orang-orang yang terlibat dalam pembuatan dan pengembangan permainan video, bukan merupakan karyawan dari game developer tersebut (misalnya penyanyi, aktor/aktris, pengisi suara, dan lainnya).

Apabila yang terjadi adalah kemungkinan pertama, maka yang menjadi pemegang hak cipta atas permainan video adalah game developer. Hal tersebut didasarkan pada Pasal 36 UUHC yang dirumuskan sebagai berikut:
"Kecuali diperjanjikan lain, Pencipta dan Pemegang Hak Cipta atas Ciptaan yang dibuat dalam hubungan kerja atau berdasarkan pesanan yaitu pihak yang membuat Ciptaan."

Lebih lanjut dalam penjelasan Pasal 36 UUHC, bahwa:

"Yang dimaksud dengan "hubungan kerja atau berdasarkan pesanan" adalah Ciptaan yang dibuat atas dasar hubungan kerja di lembaga swasta atau dasar pesanan pihak lain".

Namun terdapat hal yang patut dicatat dalam ketentuan mengenai pemegang hak cipta berdasarkan hubungan kerja. Pertama, sesuai filosofis Hegel bahwa pencipta harus selalu orang alami (natural person/ naturlijke person) sehingga jika lembaga swasta yang mungkin berbentuk badan hukum (legal entity) sebagai pemberi kerja dianggap sebagai pemegang hak cipta karena adanya presumption of transfer of exploitation right yang dibuat melalui perjanjian, misalnya kontrak kerja (Rahmi Jened, 2014: 119).

Maka lembaga swasta tersebut (dalam hal ini adalah game developer) hanya menjadi pemegang hak cipta sebatas ciptaan yang dibuat dalam lingkup pekerjaan. Artinya apabila pihak-pihak atau specialist membuat ciptaan lain di luar lingkup pekerjaannya, maka ciptaan tersebut tetap milik pihak-pihak atau specialist tersebut. Kedua, harus diingat bahwa tujuan penggunaan ciptaan bersifat terbatas. Apabila penggunaan diperluas ke luar hubungan kerja, harus 
ada izin dari pencipta dan pemberian kompensasi yang layak bagi pencipta (Rahmi Jened, 2014: 120).

Apabila yang terjadi adalah kemungkinan kedua, maka pemegang hak cipta adalah si pencipta atas ciptaan yang digunakan oleh game developer. Dalam hal ini, pengembang permainan video harus membayar sejumlah royalti kepada pencipta dan/atau kepada pemilik hak terkait. Sebagai contoh, penyanyi Katty Perry menyanyikan lagu Last Friday Night (T.G.I.F) dengan bahasa simlish (bahasa yang dipakai dalam permainan video The Sims) dalam permainan video The Sims 3: Katty Perry's Sweet Treats. Electronic Arts sebagai perusahaan permainan video The Sims, harus membayar sejumlah royalti kepada Katty Perry sebagai salah satu pencipta dan penyanyi lagu Last Friday Night dan kepada Dr. Luke dan Max Martin selaku produser atas lagu Last Friday Night.

Oleh karena itu, dapat disimpulkan bahwa apabila pihak-pihak yang terlibat dalam pembuatan dan pengembangan permainan video, bekerja di bawah game developer maka pemegang hak cipta adalah game developer dan terdapat pembatasan eksploitasi hak oleh game developer. Namun, apabila orang-orang yang terlibat dalam pembuatan dan pengembangan permainan video merupakan pihak ketiga atau tidak memiliki hubungan kerja dengan game developer, maka pemegang hak cipta tetap berada di orang tersebut sebagai pencipta.

\section{Faktor-Faktor yang Mendorong Terjadinya Pembajakan Secara Online terhadap Permainan Video}

Pelanggaran hak cipta timbul jika ada pihak lain yang melaksanakan apa yang menjadi hak eksklusif pencipta atau pemegang hak cipta secara tanpa izin. Pada dasarnya pelanggaran hak cipta dapat dikategorikan menjadi pelanggaran langsung (direct infringement); pelanggaran atas dasar kewenangan (authorization of infringements); dan pelanggaran tidak langsung (indirect infringement) (Rahmi Jened, 2014: 215). Pelanggaran langsung (direct infringement), dapat berupa tindakan mereproduksi dengan meniru karya asli. Disebut sebagai pelanggaran meskipun hanya sebagian kecil karya asli yang ditiru maupun substansial parti nya.

Dalam pelanggaran atas dasar kewenangan (authorization of infringements), yang dipermasalahkan adalah mengenai siapa yang akan bertanggung gugat jika terjadi pelanggaran. Bentuk pelanggaran ini membebankan tanggung gugat pada pihak-pihak yang dianggap mempunyai kewenangan atas pelaksanaan pekerjaan di mana pelanggaran hak cipta itu terjadi. Pada pelanggaran tidak langsung (indirect infringement), tolak ukur yang digunakan adalah bahwa si pelanggar tahu atau selayaknya mengetahui bahwa barang-barang yang terkait dengan mereka adalah hasil penggandaan yang merupakan pelanggaran (Rahmi Jened, 2014: 220). 
Dalam kaitannya dengan permainan video, pelanggaran hak cipta yang sering terjadi adalah mengenai pembajakan atau piracy. Pembajakan secara online terhadap permainan video termasuk ke dalam pelanggaran tidak langsung (indirect infringement). Hal tersebut karena si pelanggar (dalam hal ini pemilik situs penyedia video games bajakan) mengetahui bahwa penggandaan yang dilakukan adalah pelanggaran hak cipta. Pengertian mengenai pembajakan diatur dalam Pasal 1 angka 23 UUHC, bahwa :

"Pembajakan adalah Penggandaan Ciptaan dan/atau produk Hak Terkait secara tidak sah dan pendistribusian barang hasil penggandaan dimaksud secara luas untuk memperoleh keuntungan ekonomi."

Perkembangan era digital dan akses internet yang semakin cepat, membuat pembajakan secara online semakin mudah dilakukan. Orang-orang dapat dengan mudah mengakses situs-situs ilegal untuk mengunduh permainan video secara ilegal. Meskipun terdapat bahaya dalam mengunduh permainan video secara ilegal, seperti adanya virus, ransomware atau yang lebih parah adalah adanya peretasan terhadap sistem komputer, namun hal tersebut tidak mengurangi jumlah orang-orang yang mengunduh secara ilegal.

Dikutip dari website Gamebrott, perusahaan proteksi internet dan produk digital Irdeto melakukan tracking peerto-peer game olah raga tanpa proteksi. Mereka menemukan terdapat 355,664 unduhan secara ilegal dari Torrent. Terdapat 12\% (sekitar 42 ribu) dari unduhan tersebut dimulai saat permainannya telah terbajak. Hal tersebut menyebabkan kerugian sekitar 21,336,283 dolar Amerika bagi publisher maupun developer setelah mereka hitung dengan harga asli permainannya (Ayyadana Akbar, 2018).

Pembajakan permaian video secara online terjadi karena terdapat beberapa faktor yang mendorong hal tersebut, antara lain :

\section{Pengaturan terkait permainan video yang masih belum jelas}

Pengaturan dan pencegahan mengenai pelanggaran permainan video terutama pembajakan sebenarnya sudah cukup jelas, mulai dari pengertian pembajakan, pencegahan pelanggaran hak cipta dan hak terkait dalam teknologi informasi dan komunikasi, dan sanksi bagi pelaku pembajakan. Namun pengaturan terkait permainan video secara keseluruhan sebenarnya masih belum jelas. Ketidakjelasan tersebut karena kompleksitas yang terdapat dalam sebuah permainan video.

Permainan video tidak hanya sekedar perangkat lunak tetapi juga gabungan antara musik, lagu, gambar, visual, karya arsitektur, dan unsur-unsur lain yang sebelumnya telah dibahas. Oleh karena itu diperlukan satu aturan khusus mengenai permainan video, tidak hanya mengenai penegakan 
hukumnya tetapi juga mengenai hak cipta dan hak-hak lainnya yang melekat pada permainan video.

\section{Penegakan Hukum}

Dalam Teori Penegakan Hukum, secara umum penegakan hukum harus memenuhi kriteria-kriteria tertentu sebagaimana dikemukakan oleh Soerjono Soekanto (1982: 20). Terdapat lima faktor yang mempengaruhi penegakan hukum yaitu :

1) Faktor hukumnya sendiri;

2) Faktor penegak hukum, yaitu pihak-pihak yang membentuk maupun yang menerapkan hukum;

3) Faktor sarana dan fasilitas yang mendukung penegakan hukum;

4) Faktor masyarakat, yakni lingkungan dimana hukum tersebut berlaku atau diterapkan;

5) Faktor kebudayaan, yakni sebagai hasil karya, cipta dan rasa yang didasarkan pada karsa manusia didalam pergaulan hidup.

Kelima faktor tersebut di atas saling berkaitan antara satu dengan lainnya, karena merupakan esensi dari penegakan hukum dan juga merupakan tolak ukur daripada efektifitas penegakan hukum. Pengaturan mengenai permainan video yang masih belum jelas, penegak hukum yang masih kurang mengerti mengenai permainan video atau awam dengan pengetahuan dasar mengenai permainan video, kurangnya kesadaran masyarakat terhadap pelanggaran permainan video, dan kebudayaan masyarakat yang masih 'mewajarkan' adanya pembajakan. Hal-hal tersebut merupakan faktor-faktor sulitnya penegakan hukum terhadap pelanggaran permainan video.

3. Masih kurangnya kesadaran hukum dalam masyarakat mengenai pembajakan permainan video secara online

Menurut $H$. Krabbe dan R. Kranenburg bahwa "sumber satusatu hukum dan kekuatan mengikat adalah kesadaran hukum masyarakat." Dinyatakan demikian karena perasaan hukum dan keyakinan hukum individu di dalam masyarakat yang merupakan kesadaran hukum individu, merupakan pangkal daripada kesadaran hukum masyarakat (Soerjono Soekanto, 2017: 167).

Sayangnya, kesadaran hukum individu masyarakat Indonesia terkait pembajakan permainan video masih sangat rendah. Selain itu, game developer yang kebanyakan berasal dari luar Indonesia, membuat mereka sulit untuk menuntut pemilik website yang membajak permainan video asal Indonesia. Sehingga jarang terdengar mengenai kabar game developer yang menuntut pemilik website yang membajak permainan video asal Indonesia.

\section{Mahalnya harga permainan video}

Meskipun para penikmat permainan 
video mengetahui bahwa mengunduh permainan video secara ilegal merupakan hal yang salah secara moral, namun mereka tetap melakukan hal tersebut dengan alasan mahalnya harga permainan video. Berdasarkan data harga yang penulis kutip dari software permainan video Steam, harga untuk satu permainan video berkisar Rp. 50.000 hingga Rp. 700.000. Sebagai contoh, untuk permainan Cyberpunk 2077 yang baru dirilis pada 10 Desember 2020, diberikan harga sebesar Rp. 699.999 atau jika dibulatkan menjadi seharga Rp. 700.000 .

Sedangkan untuk permainan Player Unknown's Battleground (PUBG) yang dirilis pada 21 Desember 2017, diberikan harga sebesar Rp. 219.999. Selain itu, berdasarkan pengalaman penulis yang pernah membeli permainan video Left 4 Dead 2 di Steam, penulis membeli permainan video tersebut dengan harga $\mathrm{Rp}$. 18.000 (penulis mendapatkan diskon Halloween dari harga normal sebesar Rp. 69.999.). Sedangkan permainanpermainan video tersebut bisa saja di unduh secara gratis di website illegal. Oleh karena itu dapat disimpulkan bahwa, para penikmat permainan video lebih memilih untuk mengunduh secara ilegal di bandingkan harus mengeluarkan uang yang cukup besar untuk membeli satu permainan video.

\section{Banyaknya situs-situs untuk mengunduh permainan video secara illegal}

Seperti yang telah disinggung sebelumnya bahwa kemudahan untuk mengakses situs-situs ilegal, menjadi salah satu faktor pendorong banyaknya pembajakan permainan video secara online. Permainan video yang dibagikan secara ilegal melalui Torrent dan website DDL (Direct Download Link), menjadi permasalahan yang harus dihadapi game developer setiap mereka akan mempublikasikan permainan video. Lalu apakah torrent dan website DDL dapat ditutup oleh game developer video? Menurut penulis akan cukup sulit untuk menutup Torrent dan website DDL karena pada dasarnya kedua hal tersebut dibuat untuk memudahkan pendistribusian data dari satu pengguna ke pegguna lain melalui internet, terlepas dari apakah data tersebut legal atau ilegal.

Salah satu contoh kasus pembajakan yaitu ketika Nintendo mengajukan gugatan kepada situs RomUniverse.com karena telah menyediakan lebih dari 3.200 gamegame Nintendo yang berbeda, secara gratis. Situs tersebut berhasil mendapatkan 400.000 pengunjung setiap bulannya. Selain itu, RomUniverse.com juga menawarkan paket membership kepada pengguna sebesar 30 dolar Amerika per tahun untuk bisa mengunduh game-game tersebut dengan kecepatan tinggi dan tanpa batas. Selain itu, pada 
November 2018 Nintendo juga pernah melakukan hal serupa kepada situs LoveRoms.com dan LoveRetro.co. Situs tersebut juga menawarkan pengunduhan permainan video secara gratis dan mendapatkan pengunjung sebanyak lebih dari 17 juta setiap bulannya (Business Insider, 2019).

\section{Perlindungan terhadap Permainan Video yang Dibajak secara Online}

Perlindungan terhadap hak cipta merupakan hal penting bagi pencipta karena di dalamnya terdapat hak eksklusif yang dimiliki oleh pencipta. Hak eksklusif tersebut terdiri dari hak moral dan hak ekonomi (Pasal 4 UUHC). Hak moral diatur dalam Pasal 5 ayat (1) UUHC, bahwa :

"Hak moral sebagaimana dimaksud dalam Pasal 4 merupakan hak yang melekat secara abadi pada diri Pencipta untuk:

a. tetap mencantumkan atau tidak mencantumkan namanya pada salinan sehubungan dengan pemakaian Ciptaannya untuk umum;

b. menggunakan nama aliasnya atau samarannya;

c. mengubah Ciptaannya sesuai dengan kepatutan dalam masyarakat;

d. mengubah judul dan anak judul Ciptaan; dan

e. mempertahankan haknya dalam hal terjadi distorsi Ciptaan, mutilasi Ciptaan, modifikasi Ciptaan, atau hal yang bersifat merugikan kehormatan diri atau reputasinya."
Lalu, hak eksklusif lain yang dimiliki oleh pencipta atau pemegang hak cipta adalah hak ekonomi. Hak ekonomi merupakan hak pencipta atau pemegang hak cipta untuk memperoleh manfaat ekonomi atas ciptaannya (Pasal 8 UUHC). Berbeda dengan hak moral yang melekat secara abadi pada diri pencipta dan tidak dapat dialihkan selama pencipta masih hidup, hak ekonomi dapat dialihkan dengan alasan sebagaimana diatur dalam Pasal 16 ayat (2) UUHC. Pengaturan mengenai hak ekonomi, lebih lanjut diatur dalam Pasal 9 ayat (1), bahwa :

"Pencipta atau Pemegang Hak Cipta sebagaimana dimaksud dalam Pasal 8 memiliki hak ekonomi untuk melakukan:

a. penerbitan Ciptaan;

b. Penggandaan Ciptaan dalam segala bentuknya;

c. penerjemahan Ciptaan;

d. pengadaptasian, pengaransemenan, atau pentransformasian Ciptaan;

e. Pendistribusian Ciptaan atau salinannya;

f. pertunjukan Ciptaan;

g. Pengumuman Ciptaan;

h. Komunikasi Ciptaan; dan

i. penyewaan Ciptaan.”

Selain itu, pemegang hak cipta atau pemilik hak terkait juga dapat memberikan lisensi dan menerima royalti. Berdasarkan Pasal 1 angka 20 dan angka 21, dirumuskan bahwa:

"Lisensi adalah izin tertulis yang diberikan oleh Pemegang Hak Cipta atau Pemilik Hak Terkait kepada pihak lain untuk melaksanakan hak ekonomi atas 
Ciptaannya atau produk Hak Terkait dengan syarat tertentu."

"Royalti adalah imbalan atas pemanfaatan Hak Ekonomi suatu Ciptaan atau Produk Hak Terkait yang diterima oleh pencipta atau pemilik hak terkait." WIPO juga membuat program khusus terkait dengan lisensi Hak Cipta dalam lingkungan digital (Copyright Licensing in the Digital Environment). Lingkungan digital berguna untuk memfasilitasi lisensi Hak Cipta dalam berbagai cara, termasuk membantu untuk dengan cepat menemukan dan mengidentifikasi para pemberi lisensi dan penerima lisensi, menyediakan media atau wadah untuk membuat kontrak secara virtual, pembayaran royalty dan pengiriman barang dan jasa (WIPO, Copyright, Licensing in Digital Environment).

Perkembangan teknologi informasi dan komunikasi membawa pengaruh yang besar terhadap perlindungan hak cipta. Indonesia yang telah meratifikasi TRIPS Agreement, World Intellectual Property Organization Copyright's Treaty (WCT), dan World Intellectual Property Organization Performances and Phonograms Treaty, yang telah disahkan melalui Keputusan Presiden Nomor 19 Tahun 1997 (Keppres RI 19/1977) yang keduanya sering disebut sebagai digital agenda (Rahmi Jened, 2014: 141).

Negara-negara anggota berkewajiban untuk menyediakan perlindungan hukum yang layak untuk mencegah dan melawan tindak pembobolan sarana teknologi. Hal tersebut di atur dalam Article 11 WCT, bahwa: "Contracting
Parties shall provide adequate legal protection and effective legal remedies against the circumvention of effective technologies measures that are used by authors in connection with the exercise of their rights under this Treaty or the Berne Convention and that restrict acts, in respect of their works, which are not authorized by the authors concerned or permitted by law": Negara anggota harus menyediakan perlindungan hukum yang layak dan upaya pemulihan hukum yang efektif untuk melawan tindak pembobolan sarana teknologi yang efektif yang digunakan Pencipta dalam rangka melaksanakan Hak Ciptanya berdasarakan treaty ini dan Berne Convention serta tindakan yang dilarang yang terkait dengan Ciptaannya secara tanpa izin atau tindakan yang dilarang oleh hukum.

Dalam perkembangan teknologi digital, ciptaan dapat dengan mudah di distribusikan dan di akses oleh semua orang. Dampak positifnya adalah pencipta dapat dengan mudah mempublikasikan ciptaannya kepada masyarakat, pencipta mendapatkan exposure dari masyarakat dan/atau masyarakat tertarik untuk membeli ciptaan dari si pencipta atau pemegang hak cipta. Namun di sisi lain, terdapat dampak negatif dari semua kemudahan tersebut yaitu banyaknya pelaku-pelaku yang mempublikasikan dan/atau mendistribusikan ciptaan yang bukan merupakan miliknya. Pencipta atau pemegang hak cipta mustahil untuk mengontrol distribusi karya cipta mereka karena semakin cepat dan 
mudahnya penyebarluasan ciptaan yang dilanggar.

Menurut Rahmi Jened (2014: 147), terdapat tiga lapis perlindungan dalam rangka teknologi digital, yaitu:

1) Perlindungan Hak Cipta dan Hak Terkait (copyright and neighbouring right protection).

2) Perlindungan teknik untuk menutup akses (technical protection to block access), seperti encryption, scrambling, atau transformasi lain dari ciptaan atau ciptaan lain atau suatu mekanisme kontrol pengopian yang dapat menjamin perlindungan secara objektif.

3) Perlindungan hukum melawan pembobolan (legal protection against circumvention).

Salah satu upaya pencegahan terjadinya pelanggaran hak cipta dalam dunia digital adalah dengan menggunakan Digital Rights Management (DRM). DRM didefinisikan sebagai :

"Is a general term used to describe any type of technology that aims to stop, or at least ease, the practice of piracy...

DRM refers to protecting ownership copyrights of electronic content by restricting what actions an authorized recipient may take in regards to that content..."

("Adalah istilah umum yang digunakan untuk mendeskripsikan semua jenis teknologi yang bertujuan untuk menghentikan, atau setidaknya memudahkan, praktik pembajakan...
DRM mengacu pada perlindungan hak cipta kepemilikan konten elektronik dengan membatasi tindakan apa yang dapat dilakukan oleh penerima yang berwenang sehubungan dengan konten itu...").

DRM memberikan hak bagi penerbit digital content kemampuan untuk mendistribusikan secara aman dengan kecepatan tinggi. Selain itu DRM juga mengontrol penggunaan dari digital content tersebut, dan mencegah pendistribusian tanpa kewenangan atau izin. DRM adalah suatu kelas dari teknologi untuk mengontrol akses yang digunakan oleh produsen manufaktur software, penerbit dan pemegang hak cipta atau perorangan secara individual dengan tujuan atau niat untuk membatasi penggunaan peralatan digital dan isinya setelah adanya penjualan fisik dari produk digital yang bermuatan karya cipta (Rahmi Jened, 2014: 148).

Salah satu game platform yang menggunakan DRM adalah Steam. Steam menyediakan fitur-fitur tambahan seperti percepatan unduhan, penyimpanan di Cloud (Cloud storage), patching otomatis, dan beberapa pencapaian (achievements) yang tidak dimiliki dalam permainan video bajakan (jadi achievements tersebut hanya dimiliki oleh Steam) dan terkadang permainan video dalam Steam memerlukan autentikasi online atau DRM akan selalu aktif. Selain itu, pengembang permainan video dapat menarik kembali game keys yang dicuri. Hal tersebut membuat pembajakan menjadi kurang menarik karena banyaknya fitur-fitur 
yang disediakan oleh Steam.

Dalam Pasal 59 ayat (1) UUHC, perlindungan terhadap permainan video berlaku selama 50 (lima puluh) tahun sejak pertama kali dilakukan Pengumuman. Lalu mengenai pencegahan pelanggaran hak cipta dan hak terkait berbasis teknologi informasi diatur dalam Pasal 54, bahwa :

"Untuk mencegah pelanggaran Hak Cipta dan Hak Terkait melalui sarana berbasis teknologi informasi, Pemerintah berwenang melakukan:

a. pengawasan terhadap pembuatan dan penyebarluasan konten pelanggaran Hak Cipta dan Hak Terkait;

b. kerja sama dan koordinasi dengan berbagai pihak, baik dalam maupun luar negeri dalam pencegahan pembuatan dan penyebarluasan konten pelanggaran Hak Cipta dan Hak Terkait; dan

c. pengawasan terhadap tindakan perekaman dengan menggunakan media apapun terhadap Ciptaan dan produk Hak Terkait di tempat pertunjukan."

Dalam Pasal 55 ayat (1) UUHC, dirumuskan sebagai berikut :

"Setiap Orang yang mengetahui pelanggaran Hak Cipta dan/atau Hak Terkait melalui sistem elektronik untuk Penggunaan Secara Komersial dapat melaporkan kepada Menteri."
Lebih lanjut dalam penjelasan Pasal 55 ayat (1) UUHC, bahwa :

"yang dimaksud dengan "Penggunaan Secara Komersial"dalam media teknologi informasi dan komunikasi mencakup penggunaan komersial secara langsung (berbayar) maupun penyediaan layanan konten gratis yang memperoleh keuntungan ekonomi dari pihak lain yang mengambil manfaat dari penggunaan Hak Cipta dan/atau Hak Terkait dimaksud."

Dari rumusan Pasal 55 ayat (1) di atas, pemerintah menghimbau masyarakat untuk melaporkan kepada menteri jika mereka mengetahui adanya pelanggaran hak cipta dan/atau hak terkait melalui sistem elektronik untuk penggunaan secara komersial baik berbayar maupun gratis. Perlindungan lain yang dapat dilakukan pemerintah adalah menutup konten dan/atau akses terhadap situs yang menyediakan permainan video bajakan secara online. Hal tersebut diatur dalam Pasal 56 ayat (1) UUHC yang dirumuskan sebagai berikut :

"Menteri yang menyelenggarakan urusan pemerintahan di bidang telekomunikasi dan informatika berdasarkan rekomendasi sebagaimana dimaksud dalam Pasal 55 ayat (3) dapat menutup konten, dan/atau hak akses pengguna yang melanggar Hak Cipta dan/atau Hak terkait dalam sistem elektronik dan menjadikan layanan sistem elektronik tidak dapat diakses."

Lalu, untuk ketentuan pidana mengenai 
pembajakan, diatur dalam Pasal 113 ayat (3) dan ayat (4) UUHC sebagai berikut:

"(3) Setiap Orang yang dengan tanpa hak dan/atau tanpa izin Pencipta atau pemegang Hak Cipta melakukan pelanggaran hak ekonomi Pencipta sebagaimana dimaksud dalam Pasal 9 ayat (1) huruf $a$, huruf $b$, huruf $e$, dan/atau huruf $g$ untuk Penggunaan Secara Komersial dipidana dengan pidana penjara paling lama 4 (empat) tahun dan/atau pidana denda paling banyak Rp1.000.000.000,00 (satu miliar rupiah).

(4) Setiap Orang yang memenuhi unsur sebagaimana dimaksud pada ayat (3) yang dilakukan dalam bentuk pembajakan, dipidana dengan pidana penjara paling lama 10 (sepuluh) tahun dan/atau pidana denda paling banyak Rp4.000.000.000,00 (empat miliar rupiah)."

Pasal 9 ayat (1) huruf a, huruf b, huruf e, dan/atau huruf g yang dimaksud pada Pasal 113 ayat (3), meliputi penerbitan ciptaan, penggandaan ciptaan dalam segala bentuknya, pendistribusian ciptaan atau salinannya, dan/atau pengumuman ciptaan. Dalam kaitannya dengan pembajakan permainan video secara online, maka memenuhi unsur penggandaan ciptaan dan pendistribusian ciptaan.

Oleh karena itu dapat disimpulkan bahwa perlindungan terhadap ciptaan dalam era digital ini adalah sulit terutama dalam hal pembajakan permainan video secara online. Sulit karena hampir setiap game developer meluncurkan permainan video baru, mereka juga harus menyediakan perlindungan sendiri agar permainan videonya sulit dibajak. Sehingga perlindungan terhadap permainan video, harus dilakukan bersama-sama antara negara-negara anggota WIPO (termasuk negara Indonesia), game developer, dan masyarakat.

\section{KESIMPULAN}

Berdasarkan hasil penelitian dan pembahasan di atas, maka dapat disimpulkan bahwa:

1. Pemegang hak cipta dalam video games tergantung kepada apakah pihak-pihak yang terlibat dalam pembuatan dan pengembangan video games berada dalam hubungan kerja (kontrak kerja) dengan game developers atau apakah pihak-pihak tersebut merupakan pihak luar yang tidak memiliki hubungan kerja (kontrak kerja) dengan game developers. Jika pihak-pihak tersebut berada dalam hubungan kerja, maka pemegang hak cipta dalam video games adalah game developers. Jika pihak-pihak tersebut merupakan pihak luar (misalnya penyanyi) maka pemegang hak cipta adalah pencipta atas lagu yang dinyanyikan oleh penyanyi tersebut dan penyanyi tersebut memiliki hak terkait (performing rights). Selain itu, game developers juga berkewajiban membayar sejumlah royalti terhadap pencipta dan penyanyi.

2. Terdapat beberapa faktor pendorong pembajakan permainan video secara 
online, antara lain faktor pengaturan mengenai permainan video yang masih belum jelas, penegakan hukum, kurangnya kesadaran hukum masyarakat, mahalnya harga permainan video, dan masih banyaknya situs-situs untuk mengunduh permainan video secara ilegal.

3. Pencegahan dan perlindungan permainan video terhadap pembajakan online merupakan keharusan bagi negara-negara anggota yang tergabung dalam WCT dan Berne Convention. Pencegahanpencegahan tersebut berupa penutupan situs-situs yang menyediakan permainan video bajakan dan penggunaan DRM. Penggunaan DRM ditujukan untuk melindungi penggunaan digital content dan pencegahan pendistribusian tanpa kewenangan atau izin. Selain itu adanya ketentuan pidana yang diatur dalam Pasal 113 ayat (3) dan ayat (4) dalam UUHC.

\section{DAFTAR PUSTAKA}

Akbar, A. (n.d.). gamebrott.com. diakses pada 12 Desember 2020, pukul 15.23 dari Gamebrott: https://gamebrott.com/pembajakangame-saat-rilis-rugikan-developer-danpublisher-lebih-dari-21-jutaaa

Erawaty, E. (2011). Modul Pembelajaran Volume 1 : Kemahiran Umum Untuk Studi Ilmu Hukum : Membaca-MencatatMenulis Esai Akademik. Bandung: Universitas Katolik Parahyangan Bandung.
History. (2019, Juni 10). history.com. diakses pada 9 Desember 2020, pukul 23.22 dari HISTORY: https://www.history.com/topics/inventi ons/history-of-video-games

Indonesia, G. (2018, Juni 20). gamelab.id. diakses pada 10 Desember 2020, pukul 23.53 dari gamelab.id: https://www.gamelab.id/news/10mengenal-game-engine Jened, R. (2014). Hukum Hak Cipta (Copyright's Law). Bandung: Citra Aditya Bakti.

Marzuki, P. M. (2019). Penelitian Hukum Edisi Revisi. Jakarta Timur: Prenadamedia Group.

Oxford Languages. (n.d.). diakses pada 7 Desember 2020, pukul 21.08 dari https://languages.oup.com/googledictionary-en/

Soekanto, S. (1982). Sosiologi Hukum dalam Masyarakat. Jakarta: CV. Rajawali.

Soekanto, S. (2013). Sosiologi Suatu Pengantar. Jakarta: Rajawali Pers.

Webb, K. (2019, September 12). businessinsider.com. diakses pada 12 Desember 2020, pukul 18.09 dari Business Insider: https://www.businessinsider.com/ninte ndo-sues-romuniverse-copyrightinfringement-claims-2019-9? $r=U S \& I R=T$ WIPO. (2013). The Legal Status of Video Games : Comparative Analysis in National Approaches. diakses pada 11 Desember 2020, pukul 17.49 dari https://www.wipo.int/export/sites/ww 
w/copyright/en/creative_industries/pdf /video_games.pdf

WIPO. (2014, Agustus). Video Games: Computer Programs or Creative Works? diakses pada 10 Desember 2020, pukul 23.29 dari wipo.int: https://www.wipo.int/wipo_magazine/e n/2014/04/article_0006.html

WIPO. (n.d.). Copyright Licensing in the Digital Environment. diakses pada 14 Desember 2020, pukul 21.51 dari wipo.int:

https://www.wipo.int/copyright/en/acti vities/copyright_licensing.html

WIPO. (n.d.). Video Games. diakses pada 12 Desember 2020, pukul 16.17 wipo.int: https://www.wipo.int/copyright/en/acti vities/video_games.html 